\title{
АКТИВНІ МЕТОДИ ГРУПОВОГО НАВЧАННЯ: ДІАЛОГІЧНИЙ ПІДХІД
}

У статті здійснено діалогічний підхід до аналізу приниипів $i$ закономірностей активних форм і методів групового навчання. Ураховуючи методологічні уявлення про природу діалогу, запропоновано теоретичну схему аналізу діалогічних явищ $і$ прочесів у сфері активного групового навчання $i$ колективної навчальної діяльності.

Ключові слова: діалог, принциии і механізми діалогу, групове навчання, активні методи навчання.

В статье осуществляется диалогический подход к анализу принцииов $и$ закономерностей активных форм и методов группового обучения. Исходя из методологических представлений о природе диалога, предлагается теоретическая схема анализа диалогических явлений и прочессов в сфере активного группового обучения и коллективной учебной деятельности.

Ключевые слова: диалог, принципы и механизмы диалога, групповое обучение, активные методы обучения.

In the article the dialogic approach is carried out to the analysis of principles and laws of active forms and methods of the group learning. Coming from the methodological pictures of nature of dialog, the theoretical chart of analysis of the dialogic phenomena and processes is offered in the field of the active group learning and collective educational activity.

Key words: dialogue, principles and mechanisms of dialogue, group learning, active methods of learning.

Ідеї спільної діяльності, співпраці, діалогу набули величезної популярності у психолого-педагогічних науках, передовій і масовій педагогічній практиці $[1 ; 4 ; 5 ; 6 ; 7 ; 8 ; 17 ; 18 ; 19]$.

Виходячи 3 цих ідей, у сучасній вищій школі проголошено такі принципи гуманістичного навчання і спілкування, як демократизм, особистісний підхід, творчість і самореалізація, колективізм і самоврядування.

Діалогічні принципи і форми спілкування та пізнавальнотворчої діяльності є основою широкого кола новітніх напрямів і технологій практичної психології, групової психотерапії, соціальної педагогіки $[7 ; 8 ; 9 ; 10 ; 12 ; 13 ; 21 ; 22]$. У методичній і науковій літературі існує велике різноманіття активних форм і методів навчання, що виступають під назвами колективних форм організації навчального процесу, групових форм навчальної діяльності, колективної навчально- 
пізнавальної діяльності, інтерактивного навчання, навчальнокомунікативної співпраці тощо $[1 ; 4 ; 6 ; 9 ; 15 ; 16 ; 22]$. Також розроблено велику кількість форм і методів проведення ділових і ролевих ігор, дискусій і диспутів, діалогічних повчальних методів і групових творчих взаємодій $[1 ; 5 ; 7 ; 8 ; 10 ; 11$; $14 ; 17 ; 18]$. Отже, діалогічний підхід у навчанні стає фундаментальною стратегією формування у студентів соціальнокультурних знань і умінь, а також життєво-практичного й емоційно-особистісного досвіду.

Водночас, незважаючи на широке практичне використання багатоманітних форм і методів групового навчання, недостатньо дослідженими залишаються основні діалогічні принципи активних форм і методів групового навчання і спілкування.

Виходячи 3 актуальності та недостатнього теоретичного вивчення діалогічних засад активних методів навчання, мета cmammi - розробити діалогічний підхід до принципів і закономірностей активних форм і методів групового навчання $\mathrm{i}$ спілкування.

Слід зауважити, що останніми роками у вітчизняній психології і педагогіці розвивається діалогічний підхід до процесів навчання і спілкування людей, формування їхнього мислення й особистості $[7 ; 8 ; 12 ; 13 ; 19 ; 21]$. Згідно 3 цим підходом спілкування і навчання розглядаються як процеси, в яких всі учасники виступають як суб'єкти і жоден з учасників спілкування не є об'єктом однобічної дії.

У діалогічній взаємодії кожна людина, яка навчається або спілкується, є вищою метою і цінністю, яка ніколи не виступає як засіб (або тим більше матеріал) для «ліплення» людини або формування іiї особистості. Діалогічний підхід грунтується на активності суб'єкта спілкування і навчання i, у свою чергу, створює умови для виникнення і розгортання цієї активності та їі поступального розвитку.

Діалог виступає як загальний спосіб буття людини, що реалізовує унікальність і універсальність кожного 3 нас і утверджує гуманістичні відносини відвертості, рівності, взаєморозуміння і взаємодопомоги, поваги і довіри, співчуття і співпереживання, ініціативи і відповідальності [13; 21; 7; 8]. Діалог відкриває свої дійсні особливості лише тоді, коли він розглядається не як засіб досягнення інших цілей, а як самоцінне «спів-буття» людей, які реалізують своє «самобуття» $[2 ; 3 ; 7$; $8 ; 20 ; 21]$. 
Нерідко діалог намагаються осмислити недіалогічно, наприклад, зводячи його сутність і різноманіття форм до якихнебудь спрощених, об'єктно-монологічних уявлень (наприклад, що діалог - це розмова двох людей або обмін інформацією). Крім того, часто не усвідомлюється або ігнорується, що в багатоманітних ситуаціях соціально-життєвої або групової взаємодії людей виявляються різноманітні процеси і механізми діалогу.

Для аналізу обраної проблеми необхідно розглянути психологічні особливості діалогу як основи процесів навчання $i$ спілкування та охарактеризувати різноманітні вияви і форми діалогу як фундаменту методики і технології активного навчання, колективної навчальної діяльності та навчальнопізнавальної співпраці.

Перш за все діалогічний підхід передбачає розв'язання питання про сутність понять суб'єкта і об'єкта навчальнокомунікативної взаємодії. На відміну від об'єктномонологічних парадигм у діалозі суб'єктом $є$ не сам по собі індивід, але об'єктом діалогу не є й інша людина.

Справжнім суб'єктом діалогу є два або декілька учасників взаємодії, які спрямовують сумісну активність на розв'язання якої-небудь задачі, проблеми, ситуації - тобто, на об'єкт [7; $13 ; 21]$. Під час такої взаємодії, зазвичай, виявляються особистісні й індивідуальні особливості кожного учасника, а також здійснюються дії різних учасників один на одного. Водночас усі ці дії- взаємодії підпорядковані розв'язанню загальної, спільної мети - перетворенню об'єкта, під час якого кожен 3 учасників діалогу виявляє себе суб'єктом індивідуальної активності й особистісного змінення й розвитку.

У діалозі відбувається зустріч і зіткнення різних поглядів, установок, намірів і мотивів суб'єктів-учасників діалогу і завдяки їхній взаємодії розгортається породження нових мотивів і цілей. У справжньому діалозі, як правило, цілі й завдання майбутньої взаємодії не задані, не зумовлені, оскільки їх ще тільки належить знайти або виробити в процесі діалогічної взаємодії, а також визначити шляхи їх досягнення. У діалозі здійснюється спільний пошук і узгодження засобів і способів досягнення мети, рішення задачі й, нарешті, проводиться спільна оцінка успішності взаємодії.

Виходячи зі сказаного, ми пропонуємо таку схему аналізу діалогічних явищ і процесів у сфері активного спілкування i навчання, у сфері колективної навчальної діяльності. 
По-перше, для аналізу навчальної діалогічної взаємодії необхідно враховувати, на якому предметному матеріалі воно здійснюється і за допомогою якої форми взаємодіяльності реалізується. Як правило, матеріалом навчальної взаємодії учасників групового діалогу можуть бути ситуації предметно-інструментального, перцептивно-мнемічного, атенційноафективного, логіко-інтелектуального й особистісносмислового змісту. Ситуації предметно-інструментального (операційно-технічного) характеру будуть представленими набагато рідше, ніж ситуації когнітивно-вербального змісту.

По-друге, у структурі суб'єктності активного групового навчання і спілкування ми виокремлюємо фронтальні, групові й діадичні форми взаємодії. Діадичні форми взаємодії передбачають розподіл учнів на пари (діади); групові форми взаємодії здійснюються в мікрогрупах 3 кількох осіб, а також між мікрогрупами; фронтальна взаємодія не передбачає якого-небудь розподілу студентської групи або учнівського класу на підгрупи або мікрогрупи.

По-третє, за психологічним змістом розглядаються передовсім три основні типи навчально-комунікативної взаємодії: кооперативні (співпраця, взаємодопомога, інтеграція, ототожнення, зближення), конкурентні (конфронтація, конфлікт, диференціація, відособлення, віддалення) і кооперативно-конкурентні (змагання, дискусії, диспути, ділові ігри тощо). У цих взаємодіях процеси інтеграції-диференціації, ототожнення-відособлення, зближення-віддалення, взаємодопомоги-змагання тощо. багатопланово взаємопов'язані i перетинаються один з одним.

Прикладами кооперативної взаємодії є багато форм спільної навчальної діяльності: парно-діалогічне взаємонавчання (сумісний роздум і розв'язання задачі, взаємоопитування, взаємоконтроль, сумісне експериментування, проектування, вироблення оцінок або здійснення експертиз тощо); групова навчальна взаємодія, рольові ігри, багато ділових ігор (або певні їх етапи, що вимагають взаємодії членів всієї групи або кожної команди), брейн-стормінг тощо.

Конкурентні форми навчальної взаємодії - це форми суперечки, конфлікту, різноманітних дискусій (групової, рольової, альтернативної), диспуту, конкурсу, вікторини, брейн-ринга та ін.

Кооперативно-конкурентні форми можуть бути побудованими практично з будь-яких форм кооперативної навчаль- 
ної взаємодії, але в умовах змагання і розподу на команди, що дозволяє досягти оптимального розв'язання одних і тих же завдань. Як правило, більш складно-організовані форми діалогічно-навчальної взаємодії (рольові ігри, рольові дискуciї, ділові ігри, навчально-творче проектування і тому подібне) завжди містять у собі водночас і механізми кооперації, i механізми конкуренції.

По-четверте, специфіка діалогу яскраво виражається у взаємозв'язку, взаємовизначенні структури суб'єктності і психологічного змісту діалогічної взаємодії, що втілюється в понятті форми діалогу, яка може бути реально-діловою, умовно-нормативною (ігровою) і функціонально-рольовою. Отже, діалогічна форма завжди змістовна, а зміст навчальних діалогів повинен бути певним чином оформленим (тобто втіленим у конкретну організаційну форму).

По-п’яте, взаємозв'язок структури суб'єктності і психологічного змісту також істотно виявляється в типі управління взаємодією учасників діалогічного навчання. Для наших цілей достатньо виокремити пряме (директивне), непряме (організаційне) управління i самоврядування (недирективне управління). Принциповою особливістю діалогічних форм i методів навчання $є$ перевага опосередковано-організаційного і недирективного типів управління.

Визначальні потенціали діалогічного навчання, навчання у співробітництві полягають у тому, щоб поставити активність тих, хто навчається, на рівень реальної суб'єктності і щоб від зовнішнього і прямого управління навчальною взаємодією перейти до внутрішньої активації творчої активності учасників навчання, їх самоврядування і самореалізації.

По-шосте, ми виходимо з уявлення про різні рівні навчально-пізнавальної активності учасників і суб'єктів діалогічної навчальної взаємодії. В основу нашого діалогічного підходу ми покладаємо уявлення про п’ять рівнів навчальнотворчої діяльності учнів або студентів (ці рівні вперше запропоновані нами для опису й організації педагогічного спілкування [7].

Перший рівень - знання і розуміння - це рівень пасивної репродукції, на якому від учня вимагається уміння відтворити інформацію, що запам'яталася, факти, визначення, а також елементарні розумові дії: описати навчене своїми словами, зробити порівняння перефразовувати викладене іншими словами тощо. 
Другий рівень - практичного використання - звичайно, спирається на знання і розуміння, але передбачає здійснення активної репродукції вивченого матеріалу, тобто уміння застосовувати вивчений матеріал до розв'язання конкретних проблем, завдань і прикладів, а також до здійснення цілеспрямованого відпрацювання навчальних i розумових дій у процесі практичного застосування знань (тобто в процесі формування навичок і умінь).

На третьому рівні - рівні аналізу й синтезу - той, хто навчається, усвідомлює необхідність розв'язання проблемних ситуацій, що складаються в процесі виявлення причин і розпізнавання мотивів явищ, докладного розгляду матеріалу i здійснення узагальнень і висновків, аналізу висновків, результатів або висновків із метою пошуку підтверджувальних аргументів. На цьому рівні учасник діалогічного навчання висуває різноманітні припущення, розгортає міркування i роздуми, конструює розуміння і бачення загальної картини досліджуваних явищ, пропонує оригінальні або творчі рішення.

Четвертий рівень - оцінки і рефлексії - вимагає вміння оцінити переваги тієї або іншої ідеї, висловити свою думку, розв'язати якусь проблему (часто в умовах дефіциту інформації або часу), оцінювати хід і результати розумової діяльності, обгрунтовувати правомірність тих або інших дій, відкривати або узагальнювати нові способи й алгоритми розв'язання проблем і тому подібне.

П'ятий рівень - це рівень особистісно-творчого пізнання, на якому яскраво виявляються особистісно-суб'єктивні особливості пізнання як творчого самовираження, здійснюються прориви в незвідане та глибокі творчі рішення, що характеризуються оригінальністю, красою і фундаментальністю. На цьому рівні розгортаються евристико-інтуїтивні процеси мислення і пізнання, підсвідомі і смислові процеси, а накопичений досвід зумовлює виникнення нестандартних і свіжих рішень проблем.

Варто наголосити на тому, що справжнє розгортання i глибинне перетворення особистості людини здійснюється на спеціалізовані форми діалогічного спілкування - у соціальнопсихологічних тренінгах спілкування й особистісного зростання, тренінгах професійно-педагогічної компетентності, груповій і індивідуальній психотерапії. Проте, розробляючи методику діалогічних форм і методів навчання, ми виходимо 
3 визнання значних можливостей і перспектив їх упровадження як стратегій і технологій розвитку і формування вищих рівнів активності учасників навчання і спілкування.

Які ж основні форми і методи діалогічного спілкування і навчання можна виокремити? У сучасній науковометодичній літературі існують численні класифікації форм і методів активного навчання, навчальної групової взаємодії, колективної навчальної діяльності. Водночас у поглядах різних авторів є значні розбіжності відносно того, що саме є основними формами і методами активного спілкування і навчання. Так, діловою грою може називатися і рольова гра, i розроблення проектів, і групова дискусія; а поняттям «дискусія» можуть позначатися і вільна суперечка, i диспут, і групова дискусія, і рольова дискусія. Не вступаючи в розгорнуту полеміку з багатьма авторами, ми пропонуємо такі основні положення нашого підходу щодо типології діалогічних форм і методів активного навчання і спілкування.

Насамперед ми виходимо 3 того, що діалог - це багатопланове духовно-особистісне, контекстуально-ситуативне, процесуально-релятивне явище $[7 ; 13 ; 21]$. Основні особливості й характеристики діалогу (суб'єкт-суб'єктна структура, зміст, форми, рівні тощо) істотно взаємозалежними і тому зміна одного або декількох параметрів-характеристик діалогу суттєво змінює сутність і функції інших сторін діалогу. Тому форми діалогу надзвичайно рухомі й мінливі, багатопланово трансформуються одна в одну і внаслідок цього родо-видові визначення багатьох діалогічних явищ, діалогічних форм спілкування і навчання не укладаються в логічні форми традиційних об'єктно-монологічних визначень. Більш адекватним інструментом науково-методичного аналізу діалогічного навчання і спілкування стає типологічний підхід до розуміння діалогічних форм спілкування і навчання, а також розуміння закономірностей їх співвідношення і взаємоперетворення.

Як базисні форми типології діалогічного спілкування і навчання ми розглядаємо: методи проблемно-діалогічного повідомлення матеріалу, форми діадичної взаємодії, групові форми і методи навчання, рольові ігри, конкурси, дискусії, обговорення конкретних ситуацій, структурні методи аналізу і вирішення учбових завдань, методи брейн-стормінгу, командні ігри і змагання, ділові ігри та деякі інші. 
Виходячи $з$ наведених вище положень і теоретичних уявлень, ми розробили комплексну технологію діалогічних форм і методів активного групового навчання і спілкування під час навчання загальній психології [7; 8].

Наш досвід систематичного застосування активнодіалогічних форм і методів навчання і спілкування свідчить, що ці форми і методи дозволяють розв'язувати ряд важливих завдань навчання і професійної підготовки психологів і педагогів під час вивчення багатьох психологічних дисциплін.

1. Діалогічно-групові методи навчання забезпечують можливість більш глибокого i творчого засвоєння студентами психологічних знань, а також формуваня самостійної, свідомої і творчої активності у сфері психолого-педагогічної підготовки фахівців в області освіти, культури і психології.

2. Діалогічно-групові методи навчання дозволяють розвивати навчально-дидактичні знання, уміння і здібності майбутніх психологів і вчителів, надавати практичні можливості для роботи в умовах застосування активних форм і методів навчання i забезпечувати різнобічне оволодіння основними принципами, способами і прийомами діалогічного навчання i спілкування.

3.Діалогічно-групові методи навчання відкривають можливості розвивати комунікативні, організаторські й конструктивні знання, уміння, навички і здатності студентів - психологів і педагогів, а також сприяють формуванню індивідуального стилю педагогічної діяльності.

4. Діалогічно-групові методи навчання створюють умови для розкриття і розвитку особистості, вдосконалення міжособових відносин, формування згуртованості студентського колективу, a також для гуманізації професійнопсихологічного і професійно-педагогічного навчання.

Поряд із технологією діалогічного групового навчання загальній психології ми продовжуємо розроблення технологій діалогічного групового навчання іншим психологічним дисциплінам (соціальної психології, теорії та методології психології, етнопсихології, педагогічної психологіï).

На нашу думку, нині є всі підстави сподіватися, що поступове впровадження і вдосконалення технологій діалогічного групового навчання буде сприяти зростанню ефективності теоретичного навчання психології та поглибленню практичного засвоєння психологічних знань і вмінь студентами психолого-педагогічного факультету. 
Нам видається очевидним, що глибоке і фундаментальне дослідження теоретичних закономірностей діалогічного навчання та шляхів практичного використання і впровадження діалогічно-групових методів у навчання психологічним і педагогічним дисциплінам має велике значення і широку перспективу.

Ми вважаємо, що у статті зроблено перші кроки на шляху теоретичного осмислення і дослідження основних принципів i закономірностей діалогічних форм групового навчання у психології та педагогіці.

Пропоноване дослідження далеко не вичерпує всього багатства теоретичних i методичних проблем діалогічногрупового навчання. Водночас ми вважаємо, що подані у статті положення і погляди, концептуальні ідеї та технологічні принципи можуть бути цікавими і корисними для багатьох фахівців у галузях психології та педагогіки, а також для працівників сфери гуманітарних наук.

\section{Література}

1. Балаев А. А. Активные методы обучения / А. А. Балаев. М. : Профиздат, 2006. - С. 67-75. 2. Бахтин М. М. Проблемы поэтики Достоевского / М. М. Бахтин. - М. : Советская Россия, 1979. 320 с. 3. Бубер М. Два образа веры / М. Бубер. - М. : Республика, 1995. - 468 с. 4. Виноградова М. Д. Коллективная познавательная деятельность и воспитание школьников / М. Д. Виноградова, И. Б. Первин. - М. : Просвещение, 1977. - 206 с. 5. Габрусевич С. А. От деловой игры - к профессиональному творчеству / С. А. Габрусевич, Г. А. Зорин. - Минск : Университетское, 1999. - 125 с. 6. Дежникова Н. С. Товарищеская взаимопомощь школьников / Н. С. Дежникова, И. Б. Первин. - М. : Просвещение, 2011.- 80 с. 7. Дьяконов Г. В. Психология педагогического общения / Г. В. Дьяконов. - Кировоград : Изд-во КГПИ, 1992. 213 с. 8. Дьяконов Г. В. Основы диалогического подхода в психологической науке и практике / Г. В. Дьяконов. - Кировоград : Полиграфия, 2007. - 847 с. 9. Дьяченко В. К. Организационная структура учебного процесса и ее развитие / В. К. Дьяченко. - М. : Просвещение, 1989. - 224 с. 10. Емельянов Ю. Н. Активное социально-психологическое обучение / Ю. Н. Емельянов. - Ленинград : Изд-во ЛГУ, 1995. - 168 с. 11. Жуков Ю. М. Диагностика и развитие компетентности в общении / Ю. М. Жуков, Л. А. Петровская, П. В. Растянников. - М. : Изд-во МГУ, 2010. - 104 с. 12. Карпенко 3. С. Герменевтика психологічної практики 3. С. Карпенко. -К. : РУТА, 2001. - 160 с. 13. Ковалев Г. А. Три парадигмы в психологии - три стратегии психологического воздействия / Г. А. Ковалев // Вопросы психологии, 1987, № 2. - С. 41 49. 14. Крюков М. М. Принципы отражения экономической действительности в деловых играх /М.М.Крюков, Л.И.Крюкова. М. : Наука, 1998. - 205 с. 15. Лийметс Х. Х. Групповая работа на уроке / Х. Х. Лийметс. - М. : Знание, 1975. - 64 с. 16. Ляудис В. Я. 
Методика преподавания психологии / В. Я. Ляудис. - М. : Изд-во МГУ, 1984. - 82 с. 17. Павлова Л. Г. Спор, дискуссия, полемика / Л. Г. Павлова. - М. : Просвещение, 2001. - 127 с. 18. Пашукова Т. И. Методика ролевой дискуссии / Т. И. Пашукова. - Кировоград : Знание, $2008 . \quad-26$ с. 19. Психология общения и диалога учителя и учащихся / под ред. Г. В.Дьяконова. - Кировоград : Изд-во КГПИ, 1993. - 148 с. 20. Слободчиков В. И. Психология человека. Введение в психологию субъективности / В. И. Слободчиков, Е. И. Исаев. - М. : Школа-Пресс, 1995. - 384 с. 21. Флоренская Т. А. Диалог в практической психологии / Т. А. Флоренская. -М. : Изд-во НИИОПП, 2006. - 244 с. 22. Формирование учебной деятельности студентов / под ред. В. Я. Ляудис. - М. : Изд-во МГУ, 2006. - 240 с. 23. Хруцкий Е. А. Организация проведения деловых игр / Е. А. Хруцкий. - М. : Высшая школа, 2007. - 320 с.

УДК 378.011.3-051(477)

\author{
В. В. Желанова, \\ докторант, дочент, \\ Д3 «Луганський наиіональний \\ університет імені Тараса Шевченка»
}

\title{
ПРОВІДНІ НАПРЯМИ ТА ТЕНДЕНЦІї ДОСЛІДЖЕННЯ ПРОБЛЕМИ ПРОФЕСІЙНОӤ ПІДГОТОВКИ МАЙБУТНІХ УЧИТЕЛІВ ПОЧАТКОВИХ КЛАСІВ В УКРАЇНІ
}

У статті розкрито провідні напрями та тенденції дослідження проблеми фахової підготовки майбутнього вчителя початкових класів у ВНЗ на сучасному етапі, щуо збігається із запровадженням провідних ідей Болонської конвениії у систему вищої освіти в Україні.

Ключові слова: професійно значущі якості, готовність майбутнього вчителя до професійної діяльності, поліпарадигмальність, інтеграція наукових підходів, рефлексивна спрямованість, практична орієнтація освіти.

В статье раскрыты основные направления и тенденции исследования проблемы профессиональной подготовки будущего учителя начальных классов в вузе в современный период, который совпадает с внедрением ведущих идей Болонской конвенции в систему высшего образования в Украине.

Ключевые слова: профессионально значимые качества, готовность будущего учителя к профессиональной деятельности, полипарадигмальность, интеграчия научных подходов, рефлексивная направленность, практическая ориентация образования.

In the article basic directions and tendencies of research of problem of professional preparation of future teacher of initial classes are exposed in Institute of higher in a modern period which coincides with introduction of leading ideas of Bolonskoy convention in the system of higher education in Ukraine.

Key words: professionally meaningful qualities, readiness of future teacher to 